\title{
Küreselleşen Emek Piyasalarında Yeni Bir Olgu: Yetenek Yönetimi
}

Aynur YUMURTACI

\begin{abstract}
Özet
Küreselleşmenin hız kazanması ile organizasyonlar açısından başarıya ulaşmanın şartı da değişmektedir. Günümüzde farklılığın ve kalıcılığın temel unsuru yetenekli işgücünün kuruma çekilmesi, geliştirilmesi ve kurumda tutulması haline dönüşmektedir. Böylesine büyük bir rekabetin yaşandığı emek piyasalarında organizasyonların temel görevi etkin bir yetenek yönetimi sürecinin ortaya konabilmesidir. Başarılı bir yetenek yönetimi süreci ise, organizasyon içerisindeki tüm yetenek yöneticilerinin uygulayacağ ${ }_{1}$ aktif politikalarla sağlanmaktadır. Bu noktada organizasyon için en uygun yetenek yönetimi stratejisinin iş stratejileri ile birlikte belirlenmesi önem arz etmektedir. Bu çalışmada yetenek yönetimi; taşıdığı önem, kurum içi işlerin, çalışanların yapısı ve tüm yetenek yöneticileri bakımından ele alınmaktadır. Ayrıca yetenek yönetiminin küresel emek piyasalarındaki durumu incelenmekte ve genel değerlendirmelerde de bulunulmaktadır.
\end{abstract}

Anahtar Kelimeler: Emek, İnsan Kaynakları, Küreselleşme, Yetenek, Yetenek Yönetimi.

A New Phenomena On The Globalized Labor Markets: Talent Management

Abstract

From the view of organizations, requirement for reaching to success is changed by the acceleration of globalization. Today, attracting skilled labor to the organization, developing talent and retention of talent are turning over the main facts for difference and permanance. The basic mission of organizations is able to put an effective talent management process on such a great competition in labor markets. A successful talent management process is provided by using active talent management policies with all talent workers-managers. At this point, it is important to determine with the most appropriate talent management strategies with job strategies. In this study, the importance of talent management, the structure of in house works, the structure of employees is handled by the frame of the all talent managers/managers. Also, the status of talent management on the global labor markets is examined and general assessments are performed.

Keywords: Labor, Human Resources, Globalization, Talent, Talent Management.

* İstanbul Üniversitesi SBE Çalışma Ekonomisi ve Endüstri İlişkileri ABD Doktora Öğrencisi, e-posta: aynur.yumurtaci@gmail.com, ayyumurtaci@yahoo.com 


\section{Giriş}

Tarihin ilk dönemlerinde insanlar için önemli olan temel ihtiyaçların karş1lanabilmesi; yemek, barınmak, çevreden gelebilecek tehlikelerden korunmak iken, bu durum zamanla değişime uğramıştır. Özellikle dünyada yaşanan hızlı nüfus artışı ve yeni teknolojilerin ulaşılabilirliği ile ihtiyaçlar çeşitlenmektedir. Böylece 21.yy'ın insanı sadece temel ihtiyaçların peşinde koşan insan profili olmaktan uzaklaşmış olup hep daha mükemmeli ister hale gelmektedir. Bu durum kurumsal açıdan düşünüldüğünde, günümüzde varlığını devam ettirebilmek isteyen organizasyonlar için üretimin çeşitliliği ve insan ihtiyaçlarına daha iyi hizmet temel hedef halini almaktadır. Bu hedefi gerçekleştirebilmenin yolu ise, kurum için stratejik önem arz eden işleri belirleyip bu işlerde çalışacak yeteneklerle işbirliği içinde olmaktan geçmektedir.

Bununla birlikte bilgi teknolojilerinin getirdiği kolaylık sayesinde işverenler kendi kurumlarına ait insan kaynakları yönetim stratejilerini küresel emek piyasalarını takip ederek belirlemektedirler. Günümüz insan kaynakları yönetimi anlayışının yeniden yapılandığ 1 bu aşamada kurumlar kendi stratejileri ile uyumlu ve kurumu başarıya taşıyabilecek yeteneklere ulaşabilmek adına adeta yetenek için savaş verir durumu gelmektedirler. Ancak bu noktada yetenek yönetimi anlayışı tek başına sihirli bir değnek olarak da düşünülmemelidir. Öyle ki yetenek yönetimi ile ilgili bulguların bütün kurumlara aynı şekilde uygulanmasının mümkün olmadığı altı çizilmesi gereken önemli bir konu halini almaktadır. Bu durum her kurumun aynen her birey gibi farklı özelliklere sahip olmasından kaynaklanmaktadır. Aynı işkolunda üretim yapan iki kurumda bile yetenek yönetimi uygulamalarının aynı olması beklenmemektedir. Yetenek yönetimi uygulamalarında yola çıkış noktası teorik ve pratik uygulamaları takip ederek özgün bir sistem oluşturmaktır. Bu sistemi oluşturmanın yolu ise, kurumu iyi tanımak ve uygulanacak stratejileri iyi seçmekten geçmektedir.

$\mathrm{Bu}$ çalışma ile; günümüz emek piyasalarında yetenekli işgücünün etkili bir biçimde yönetilebilmesi için uygulayıcılar ve çalışanlar açısından yetenek yönetiminin taşıdığı önemi ortaya koymak hedeflenmektedir. Bu doğrultuda, öncelikle yetenek yönetim sürecine zemin hazırlayan gelişmeler incelenerek yetenek yönetiminin içeriği belirlenmektedir. Ardından yetenek yönetiminin önemine değinilmekte ve bu süreçte yer alan çalışanların ve işlerin sınıflandırılması yapılarak yetenek yöneticilerinin yetenek yönetiminde izlemesi gereken stratejiler üzerinde durulmaktadır. Çalışmanın son kısmında ise, küresel piyasalar açısından açıklamalar yapıldıktan sonra genel değerlendirmelere yer verilmektedir. 


\section{Toplumsal Yapıdaki Değişim ve Değişen Emek Piyasaları}

İnsanlığın varoluşundan bugüne kadar toplumlar hayatlarını devam ettirebilmek için üretim sürecinin içerisinde aktif olarak yer almışlardır. Üretim faaliyetlerinin genel yapısına bakıldı̆̆ında ortaya çıkan sosyal ve ekonomik farklılaşmalar ile süreç içerisinde emeğin yapısının da değişime uğradığını söylemek mümkündür. Bu açıdan üretim sürecinin yapı taşı olan insanın ve dolayısı ile toplumların değişimlerini daha net anlayabilmek için öncelikle toplumsal dinamiklerdeki değişimlere bakmak gerekmektedir.

Toplumsal yaşamın ilk aşamasında insanlar belirli sayılardaki küçük gruplar (bu topluluklar genellikle otuz ya da kırk kişiden oluşmuş gruplardır) halinde avcı ve toplayıcı toplumlar olarak yaşamışlardır. Bu toplumların üretim sürecine olan etkisine bakıldığında iş bölümünün son derecede önemli olduğu görülmektedir. Ayrıca kimi avcı ve toplayıcı toplumlar yaşamlarını sürdürebilmek ve artan nüfuslarına bakabilmek için evcilleştirilmiş hayvanlarını yetiştirmeye ve belirli toprak parçalarını ekerek yılın tüm zamanında bu topraklar üzerinde yerleşik düzende yaşamaya başlamaktadırlar. Emeğin etkinliği ve üretim süreci açısından bakıldığında kadın, erkek ve çocuk işgücü bir arada çalışmaktadır (Giddens, 2000, s. 48-54).

Bununla birlikte tarım toplumunun bir diğer karakteristiği de bilginin deneyim yolu ile elde edilmesidir. Bu durum insanların işleri yaparak öğrendikleri anlamına gelir. Tarım toplumlarının üretim yapısı usta-kalfa-çırak ilişkisi biçiminde şekillenmiştir. Usta-kalfa-çırak adı verilen bu üçlü yapıya "lonca" adı verilmektedir. Ancak 16.yüzyılın sonlarına gelindiğinde lonca teşkilatında değişimler yaşandığı bilinmektedir. Özellikle nüfus artışı ile birlikte loncaların pazarın artan ihtiyaçlarını karşılayamadıkları görülmektedir. Bu duruma ek olarak yeni ve farklı iş sahalarının ortaya çıkışı lonca teşkilatının işleyişini iyice sarsmıştır. İşte tüm bu bahsedilen durumlar artık daha farklı bir düzenin gerekliliğini ortaya çıkarmıştır.

Özetle modern öncesi toplum olarak ifade edebileceğimiz ilk toplumların ardından yerleşim dinamiklerinin nüfus artışına paralel olarak değişmesi, genişlemesi karşımıza "şehirleşme" adı verilen yeni bir sosyal düzeni, böylelikle yeni üretim şekilleri ve emek piyasası dinamiklerini çıkarmıştır. Bunun en önemli sonucu ise, üretim sürecinde geçim ekonomisi kavramının yerini pazar ekonomisine bırakmasıdır. Pazar ekonomisinin ön plana çıkması ile sanayi toplumlarının temel karakteristiği belirlenmektedir. Buna göre sanayi toplumunda yer alacak emek işbölümünün yanı sıra modern öncesi toplumlardan ihtisaslaşma ile de ayrılmaktadır. Bunun temel nedeni üretilen mallarda ve üretim metotlarında devamlı ve hızlı değişmeler olması ve işgücünün vasıf ve sorumluluklarının da buna göre değişmesidir (Seyyar, 2002, s. 456). 
Böylelikle 18. yüzyılın sonunda sanayileşmenin meydana getirdiği yeni üretim biçimleri ve emeğin değişen yapısı ile ev içi üretim etkinliğini yitirmiştir. Ancak bu değişim beraberinde farklı sorunları da getirmiştir. İşletmelerde kitle üretimini gerçekleştiren makineleşme ile üretimde emeğin değeri ikinci sıraya yerleştirilirken makineler ön plana çekilmiştir. Makineleşmenin getirdiği süreç emek üzerinde monotonlaşmaya sebep olurken bir süre sonra eser üretmenin insan psikolojisine sağladığı tatmin olgusu da ortadan kalkmıştır. $\mathrm{Bu}$ durum yeni örgütsel ve yönetsel sistemleri doğurmuştur. Böylece 20.yüzyılın başlarında yönetsel ve örgütsel psikoloji süreçte yerini almıştır (Eren, 2004, s. 9-10).

Bahsedilen toplumsal yapıdaki değişimler ve üretim sürecindeki yansımalarda da görüldüğü gibi, sanayi toplumunda sırası ile; sermaye, doğal kaynaklar ve emek temel üretim faktörlerini oluştururken, endüstriyel psikoloji uygulamaları, personel yönetimi ve izleyen aşamalarda insan kaynakları yönetimine geçiş ile birlikte değer yaratmanın kaynakları verimlilik ve yenilik olarak görülmektedir. Verimlilik ve yeniliğin hayat kazanabilmesinin en önemli şartı da bilginin işe uyarlanması ile yani emeğin gelişimi ile mümkün olmaktadır (Aykaç ve diğ., 2009, s. 55-60).

Günümüzde küreselleşme olgusunun hız kazanması ile birlikte bilgi kalkınmanın en önemli anahtarı olmuş ve rekabetin vazgeçilmez bir unsuru haline gelmiştir. Bilgi toplumuna geçişte stratejik kaynak artık eskiden olduğu gibi çoğunlukla sermaye değil, bilgidir. Yeni ekonomide bilgi ve teknolojinin kişisel üretime uygulanması başarının önemli unsuru halini almaktadır. Özellikle üretilen son teknolojiler ve dijitalleşme ile bilgi için artık mesafelerin önemi de ortadan kalkmıştır (Tonta \& Küçük, 2005, s. 4). Böylelikle bilgi artık istenildiği zaman depolanabilen ve transfer edilebilen bir yapı haline gelmiştir. Doksanlı yılların başında önemi daha da artan yeterliliğe dayalı insan kaynakları yönetimi uygulamalarının da dünyada hız kazanması ile artık işgücünün yönetilmesinde ve etkinliğinde yeni bir kavram hayat bulmuştur. İşte bu kavram "yetenek" ve beraberinde "yetenek yönetimi”"dir. Artık küresel piyasalarda asıl amaç, yetenekleri keşfetmek, geliştirmek ve kurum içinde tutmaktır (Ulrich ve diğ., 2012, s. 168-170 ). Günümüz gelişen teknolojileri, bilgi transferi, yeterlilik ve yetkinlikler ile izleyen süreçte ön plana çıkan yetenek kavramının önemi artık bambaşka bir boyuta taşınmıştır. $\mathrm{Bu}$ yeni boyutta eskiden maliyet unsuru olarak görülen emek, konunun önemini kavrayan organizasyonlarca öncelikle kurumların en kıymetli varlığı olmuş, sonrasında da her çalışan bulunduğu işletmeye değer sağlayan birer yetenek olarak nitelendirilmiştir. Bu durum yeteneğe atfedilen önemin gelecekte daha da ön plana çıkacağının bir göstergesidir (Doğan \& Demiral, 2008, s. 145146). 


\section{Kavramsal Açıdan Yetenek ve Yetenek Yönetimi}

Günümüzde yetenek kavramına verilen önemin artması neticesinde bu kavram ile yoğun bir şekilde karşılaşır olduğumuz gerçektir. Yetenek kavramı gerek ikili ilişkilerde, gerekse de yazılı ve görsel medyada sıklıkla karşımıza çıkmaktadır. Öyle ki birçoğumuzun günlük yaşantımızda duyduğumuz genel yetenek, özel yetenek, fiziki yetenek, yetenekli insan, yetenek havuzu, yetenekli çalışan, yetenek yıldızları gibi kavramlar yetenek kavramının yaşantımız ile ne derecede iç içe olduğunu gösteren küçük birer örnek olarak kabul edilebilir. İşte bu noktada yeteneği iyi anlayabilmenin yolu yeteneği düzgün bir biçimde tanımlayabilmek ve onu diğer kavramlar ile ilişkilendirebilmekten geçmektedir.

\subsection{Yetenek Kavramı}

Genel anlamda yetenek, bir duruma uyma konusunda organizmanın yapısı içerisinde yer alan, doğuştan gelen kapasite ve güç olarak tanımlanmaktadır. Türk Dil Kurumu (TDK) başka bir tanımda yeteneği, bir kimsenin bir şeyi anlama veya yapabilme niteliği, kabiliyet olarak ifade etmektedir (TDK Sözlüğü, 1988, s. 1626).

Farklı bir ifade ile yeteneği tanımlarsak; bu tanımda İngilizcede yetenek anlamına gelen "TALENT" kelimesinin baş harfleri kullanılarak yeteneğin tanımının yapıldığ 1 ve içeriğinin belirlendiği söylenebilir. Bu tanıma göre yetenek;

T (Triumph) Başarı, A (Ability) Kabiliyet, L (Leadership) Liderlik, E (Easiness) Kolaylaştırmak, N (New Fangle and Creativity- Innovation) Yaratıc1lık ve Yenilik, T (Time) Zaman ve zamanı etkin kullanmanın bütünü olarak tanımlanmıştır (Buzzle, ty.).

Blass ise yeteneği, kişinin sahip olduğu potansiyel, göstermiş olduğu performans ve kritik becerilerin bir bütünü olarak açıklamaktadır (Blass, 2007, s. 3).

Yetenek kavramı ile ilgili araştırmaları olan Marcus Buckingham ve Richard M. Vosburg ise, yetenek kavramını anlayabilmek için öncelikle yetenekle ilişkilendirilen bilgi ve beceri kavramlarını tanımlamaktadırlar. Buna göre bilgi; hem varlığı bilimsel olarak kanıtlanmış kesin ve gerçek olguları, hem de bu gerçekleri uygularken yanlışlardan öğrenilen soyut kavramları içerirken beceri; bir işi yapabilmek için belirli bir tekniği ya da metodu uygulama kabiliyeti olarak ifade edilmektedir. Yetenek ise, bir kişinin sürekli yaşadığı duygu, düşünce ve davranışları üretici bir biçimde hayatın her alanında uygulayabilmesini içermektedir (Lider insan, 2009, s. 1). Bu tanımlardan hareketle yeteneğin belirli bir potansiyel gerektirdiği, bilgi ve beceride ise, sonradan 
öğrenmenin yeteneğe göre daha ağır bastığı görülmektedir. Başka bir değişle yetenekler doğuştan gelirken beceriler büyük oranda gelişimin ve değişimin unsurlarını oluşturmaktadır. Ayrıca birçok becerinin temelini yetenekler oluşturduğu gibi becerilerde farklı yeteneklere bağlanmaktadır. Yetenek ile ilgili olarak yapılmış tanımları ortak bir paydada buluşturarak yetenek kavramını yeniden tanımlayacak olursak, çoğunlukla doğuştan gelen, davranışları etkilediği gibi davranışlardan etkilenen, belirli bir potansiyeli içeren ve bu potansiyel üzerinde farkl11ıklar doğuran zihinsel ve bedensel kapasitelerimiz yetenek olarak tanımlanmaktadır.

\subsection{Yetenek Yönetimi Kavramı}

Yetenek ile ilgili olarak yapılan tanımlara bakıldığında genel anlamda yetenek tanımının pek çok alanda kullanıldığı görülmekle birlikte kavramın eskilere dayandığını (M.Ö. 6. yy.'da Yunanistan'ın güneyinde bulunan Eski Sparta'da askeri alanda yetenek kavramı kullanılmıştır) söylemek mümkündür (Budak, 2008, s. 165).

Buna karşı1ık uygulamadaki yönetim anlayışının kazandığı yenilikler ile ortaya çıkan yetenek yönetimi kavramının tarihi ise, tek başına yetenek kavramı kadar eski değildir.

Yetenek yönetiminin ön plana yerleşmesini sağlayan çalışmalar Amerika'nın en büyük yönetim danışmanlığı şirketi olan Mc Kinsey \& Company tarafından 1997 yılında gerçekleştirilmiştir. Bu çalışmalarda Mc Kinsey \& Company "Yetenek için Savaşlar" adı altında yetenek yönetiminin önemine dikkat çekmektedir. Mc Kinsey \& Company'nin yaptığı çalışmada 77 büyük ölçekli kurumda çalışan 6000 civarında yönetici ile gerçekleştirilen görüşmede performansta artı̧̧ ve verimlilik sağlamanın temel kaynağının yetenekler üzerine odaklanmak olduğu ifade edilmektedir. Mc Kinsey \& Company 2000 yılında araştırmanın ikinci ayağını da tamamlayarak toplam 13000 yönetici ve 112 büyük ölçekli şirket ile görüşmelerini gerçekleştirmiş̧tir. Buna göre başarının temel kaynağ 1 yeteneği doğru bir biçimde yönlendirmek ve yönetmekten geçmektedir (Mc Kinsey \& Company, 2001, s. 1).

Yetenek yönetimi ile ilgili olarak farklı araştırmacıların farklı tanımları olmasına rağmen Mc Kinsey\&Company'nin Yetenek tanımı şöyledir; yetenek kişilerin sahip olduğu bilgi, beceri, tecrübe, zeka, yargılama, tutum, davranış ve karakterlerin bir bütünü olup bu kavramların geliştirilmesidir. Bu uygulamanın yönetsel sistemde işlerlik kazanması da "yetenek yönetimi" olarak ifade edilmektedir.

Ünlü insan kaynakları gurusu David Ulrich'e göre yetenek yönetimi, bugün ve yarın ihtiyaç duyulacak bilgi, beceri ve değerlerin yönlendirilmesidir. 
Ulrich'in yetenek yönetimi tanımı derinlemesine incelendiğinde yeteneği üç boyut içerisinde değerlendirdiği görülmektedir. Bu boyulardan ilki "Yetkinliktir". Yetkinlik bugün ve yarın için gerekli bilgi, beceri ve değerlerin toplamını içermektedir. İkinci boyut "Taahhüt" boyutudur. Taahhüt organizasyonun başarısı için gerekli enerjinin bütününü oluşturmaktadır. Son boyut ise, "Katkı" boyutudur. Organizasyonel düzeyde katkı işi anlamlandırmak ve amaca hizmet etmektir (Beechler \& Woodward, 2009, s. 275).

Lewis ve Heckman tarafindan yapılmış bir diğer yetenek yönetimi tanımında kavram girdi, süreç ve çıktı bazında özelleştirilerek belirli bir temele oturtulmaktadır (Polat, 2011, s. 3). "Girdi” olarak yetenek yönetimi; yetenek arzının ve talebinin yönetilmesi, seçme yerleştirme sürecinde uygulanması gereken bir başarı planıdır. "Süreç" olarak yetenek yönetimi; Anahtar pozisyonlardaki liderliğin devamının sağlanması ve bu yönde yetenek havuzu oluşturulması yönündeki çabaların bütünüdür. Son aşamada "Çıktı" olarak yetenek yönetimi yaklaşımı ise, doğru zamanda ve doğru yerde doğru kişilerin çalışmasıdır (Lewis \& Heckman, 2006, s. 2).

Yetenek yönetimi ile ilgili olarak yapılmış farklı bir tanımda bu kavram, organizasyonlar arasındaki yarışta başarıyı yakalayabilmek için yüksek potansiyel ve yüksek performansa sahip kişilerin yetenek havuzuna alınarak organizasyonun farklı iş birimlerinde yer almalarının sağlanması olarak ifade edilmektedir (Collings \& Mellahi, 2009, s. 7).

Yetenek yönetimi Evans, Pucik ve Björkman'ın tanımı ile, organizasyonel çıktılar üzerinde belirgin öneme sahip kişileri firmaya çekmek, seçmek, yerleştirmek, geliştirmek ve elde tutmak yönündeki faaliyetler bütünüdür. Evans, Pucik ve Björkman'a göre dünyada yetenekli insan bakımından herhangi bir kıtlık bulunmamaktadır. Asıl sorun doğru insanların doğru yerde olmamasıdır. $\mathrm{Bu}$ açıdan çalışanları doğru işlere ve kurumlara yönlendirmek ve maksimum değer üretmek oldukça önemli bir durum haline dönüşmektedir (Stan, 2012, s. 5).

Yetenek yönetimi ile ilgili olarak yapılmış tüm tanımlara bakıldığında hepsinin ortak noktasının etkinlik ve verimliliği arttırmak olduğu görülmekle birlikte kavram ile ilgili olarak tek bir tanım bulunmadığı anlaşılmaktadır. Buradan çıkarılması gereken en önemli sonuç her kurumun kendine göre bir yetenek yönetim sistemi oluşturup bu sistemi tanımlaması ve bunu stratejik boyutta uygulamaya taşıyabilmesidir. 
194 • YALOVA SOSYAL BİLIMLER DERGİSİ

\section{3. İnsan Kaynakları Yönetiminin Değișen Yapısı ve Yetenek Yönetiminin Önemi}

Günümüzde insan kaynakları yönetimi olarak anılan ve kurumların gelişiminde stratejik öneme sahip olan yönetim anlayışı kısa bir süre içerisinde hayata geçmemiştir. İnsan Kaynakları Yönetiminin ortaya çıkışı ve günümüzdeki noktaya ulaşmasında tarihsel süreçler içerisinde yaşanan sanayi devrimi, uluslararası piyasalarda yaşanan hareketler bir diğer ifade ile küreselleşme büyük rol oynamıştır.

İnsan Kaynakları Yönetiminin temelleri aslında çalışma ilişkileri ya da personel yönetimi anlayışından da ötedir. Çalışanların ücret oranları ve bunlarla ilgili ilk kanunlar Babilli Hammurabi tarafından M.Ö. 1800'lü yıllarda ortaya atılmıştır. Ayrıca M.Ö. 1650 yılında Eski Çin'de kullanılmış olan işbölümü ve personel devri kavramları ve bu kavramların uygulamaları ilk kez insan kaynaklarına geçişin temellerini oluşturmaktadır.

Bununla birlikte günümüze daha yakın tarihlere bakıldığında 1900'lü yılların başında kurum içerisinde çalışanlara ait günlük dosyaları tutmak, vergi hesaplamalarını ve maaş hesaplamalarını yapmak, günlük devamsızlık ve devam listelerini oluşturmak önceki dönemlerde personel bölümünün faaliyet alanı altında gerçekleşirken bu süreç aslında gelecekte şekillenecek stratejik insan kaynakları yönetiminin temelini atmıştır. 1900'lü yılların başından 1950'li y1llara kadar İnsan kaynakları yönetimi ve biriminden çok personel yönetimi anlayışının etkin olduğu görülmektedir. 1900'lü yılların ortalarına gelindiğinde yasal sorumlulukların artması ve prosedürlerin yürütülmesi ile personel seçimi, ücretlendirme ve eğitim gibi fonksiyonlarla insan kaynakları birimlerinin etkinliğinin arttığı görülmektedir. 1980'li yıllar ile küreselleşmenin artan önemi beraberinde yeni yönetim stratejilerini doğurmuş ve insan kaynakları yönetimi daha da önem kazanmaya başlamıştır (Okakın, 2005, s. 1). Ortaya çıkan stratejik insan kaynakları uygulamaları ile birlikte 20.yy'ın son çeyreğinde küresel işgücü piyasalarında rekabetin hız kazanması, bilgi teknolojilerinin ön plana çıkması beraberinde farklı uygulamaları getirmiştir. Özellikle bilginin artan önemi ile beraber artık insan kaynakları departmanları farklılık ve daha fazla farkındalık yaratmak için yetenek yönetimi uygulamalarına geçmektedirler (Ceylan, 2007, s. 19). Bu süreçte personel yönetiminden insan kaynakları yönetimine geçişte yaşanan durumun, insan kaynakları yönetiminden yetenek yönetimine geçişte yaşanacağı düşünülmektedir. Günümüz insan kaynakları yönetimi anlayışının işgücünün gerek yerel, gerekse de küresel emek piyasalarındaki hareketini önemle takip ettiği ve uzun dönem stratejilerini yetenek yönetimi uygulamalarına göre şekillendirmeye çalıştığı görülmektedir. Slywotzky bu durumu günümüz üretim anlayışında kar ve de- 
ğer yaratmanın değişen unsuru olan işgücünden yola çıkarak "Değer Göçü" kavramı ile ifade etmektedir. Slywotzky'nin “Değer Göçü” anlayışına göre; değer göçü yaklaşımını kavramış olan bir insan kaynakları yöneticisinin her pozisyon için farklı yeteneklere sahip işgücünü kuruma çekebilecek yaklaşıma sahip olması gerekmektedir. Böylelikle mevcut yeteneklerin geliştirilmesi sağlanarak gerçek anlamda iş başarısından söz edilebilmektedir. Bu durumda yetenek yönetiminin, insan kaynakları yönetiminin temel işlevi haline geleceği düşünülmektedir (Eroğlu, 2001, s. 1).

Günümüzde yetenek yönetimi yönetici konumunda çalışan pek çok kişinin dikkatini çekmekle birlikte özellikle üst düzey yöneticiler tarafindan üzerinde önemle durulan bir konu halini almaktadır. Farklı büyüklükteki şirketlerin üst düzey yöneticileri ile yetenek yönetimi üzerine "The Economist" dergisinin yapmış olduğu araştırmada üst düzey yöneticiler zamanlarının yaklaşık olarak \%30-50'lik kısmını yetenek yönetimine harcamaktadırlar. Ayrıca her on üst düzey yöneticinin yedisi zamanının \%20'sini yetenek yönetimine harcamaktadır (Stan, 2012, s. 6). Yakın döneme kadar insan kaynakları yönetiminin temel odak noktası liderlik ve gelişim iken, son birkaç yılda yetenek yönetimi pek çok kurumun gündemine oturmuş olup organizasyonların temel ilgi alanı haline gelmektedir (Davis, 2011, s. 1). Bununla birlikte günümüzde etkin bir yetenek yönetimi uygulaması ile kurumlar şu sorulara yanıt aramaktadırlar;

> Yetkinlik temelli seçim süreci ile daha etkili bir yerleştirmeyi nasıl bir yönetim süreci ile gerçekleştirebiliriz?

> Sürdürülebilir liderlik yaratmak, kültür ve değerleri kuvvetlendirebilmek için daha etkin yönetim ve liderliği nasıl sağlayabiliriz?

$>$ Her türlü eğitim ve gelişim programı ile mevcut pozisyonlar hızlı bir biçimde nasıl doldurulabilir? Doğru kişileri işe almak için mevcut pozisyonları nasıl kullanabiliriz?

> Tutarlı ve ölçülebilir yollarla insanları nasıl yönetebiliriz?

> Tepkisel ve yüksek derecede esnekliğe sahip organizasyonlar olduğumuzdan emin olmak için yüksek performans ve başarı gerektiren anahtar pozisyonları nasıl tanımlarız?

$>$ Uygun, esnek, güvenli ve zamanlı bir biçimde öğrenmeyi nasıl sağlar1z?

Tüm bu sorulara aranacak yanıtlarla kurumsal anlamda yetenek yönetimi sürecinin taşıdığı önem bir kez daha vurgulanmaktadır. Yetenek yönetimine bu derecede önem verilmesinin sebepleri ise şu şekilde sıralanabilir. 


\section{> Yetenek ve iş performansı arasındaki doğru orantılı ilişki}

Günümüzde şirketler artan yetenekler karşısında hem kurumsal, hem de bireysel performansın artış gösterdiğini ortaya koymaktadırlar. Örneğin 2007 y1lında yapılmış bir araştırmaya göre Hackett Grubuna ait şirketler yetenek yönetimi uygulamaları ile piyasada kendileri ile aynı faaliyeti gösteren şirketler karşısında \%15 daha fazla kazanç sağlamışlardır. Yetenek yönetimi ve iş performansı arasındaki doğru orantılı ilişkiye verilebilecek bir diğer örnek ise IBM'de uygulanan yetenek yönetimi uygulamalarıdır. Bu uygulamalar sonucunda IBM finansal açıdan kar sağlamıştır.

\section{> Dĕger yaratmanın kaynağı olarak yetenek yönetimi}

Brooking Enstitüsü'nün 1982 y1lında gerçekleştirdiği bir araştırmada ortalama büyüklükteki şirketlerin değer yaratması \%62'lik bir oranla sahip oldukları somut - fiziksel (makine, teçhizat) unsurlara bağlı olmaktadır. Geriye kalan \%38'lik kısım ise, entellektüel sermaye gibi soyut değerleri içermektedir. Geçen süreç içerisinde 2003 yılında yapılan bir araştırmada her şey değişmiş ve oranlar tersine dönmüştür. Buna göre değer yaratmanın kaynağ $\%$ \% 8 'lik oranla emeğe bağlanırken, \%20'lik oranla somut değerler olan makine, teçhizat ikinci plana yerleşmiştir.

\section{> İşlerin daha fazla karmaşıklaşması ve dinamikleşmesi}

Yeni ürünler ve yeni iş modelleri ile, artık ürünlerin piyasadaki ömrü eskisi kadar uzun olmamakta, bilgi teknolojileri ve yenilik yaklaşımının sosyo-ekonomik hayatta yaygınlık kazanması ile artık şirket merkezi belirli bir bölgeye yerleşirken üretim ve satışın yapıldı̆̆ 1 yerler farklılaşmaktadır. $\mathrm{Bu}$ farklılaşma ve dinamikleşme içerisinde hem ekonomik gelişme sağlamak, hem de kalıcılığı yakalamanın temel yolu doğru zamanda, doğru yerde, doğru kişinin çalıştırılmasından yani planlanmış bir yetenek yönetiminden geçmektedir.

\section{$>$ Piyasanın daha iyiyi arayış içerisinde olması}

Günümüz üst düzey yöneticilerinden yetenek yönetimi adına beklenen davranış sadece en iyi performans gösteren çalışan grubunu yetenek yönetiminin hedefleri doğrultusunda yönetmek değildir. Tüm seviyelerdeki çalışanların sahip oldukları yeteneğin kalitesini ortaya çıarabilecek ve geliştirebilecek davranışlar sergilemeleri üst düzey yöneticilerden beklenmektedir (Wellin ve diğ., ty., s. 2-4). Bu doğrultuda üst düzey yöneticiler ve birim yöneticilerinin 
insan kaynakları birimleri ile kuracakları aktif iletişimin yetenekli çalışanlar üzerinde pozitif bir etki oluşturması beklenmektedir.

\section{> Çalışan beklentilerindeki değişmeler}

İşgücü piyasasının değişen yapısı ve küresel piyasalardaki farklılaşmalarla birlikte şirketlerin yetenek yönetimine verdikleri önem kadar çalışanlarında bu yöndeki beklentileri değişime uğramaktadır. Bugünün çalışanları kendileri için daha fazla anlam ve önem taşıyan işlerde çalışmak istemektedirler. $\mathrm{Bu}$ grupta çalışanlar için işe sadıklık organizasyona sadıklıktan daha önemli bir durum halini almaktadır. Ayrıca günümüz çalışanları iş ve hayat dengesi ile daha fazla ilgilenmek ile birlikte ayn zamanda kariyerlerini planlama ve geliştirme eğilimindedirler. Bu durumda şirketlerinde işgücü piyasasındaki bu değişime göre hareket ederek yapısal anlamda değişim ve gelişim göstermeleri gerekmektedir. Böylelikle istenilen seviyede işgücünün kuruma çekilmesi ve elde tutulması hedeflenmektedir (Ceylan, 2007, s. 19).

\section{> İşgücünün demografik yapısındaki değişimler}

İçerisinde bulunduğumuz dönemde işgücü piyasasında yer alan çalışanların \%60'1nı 60 yaş ve üzeri çalışan grubu oluşturmaktadır. 60 yaş ve üzeri bu grupta çalışanların emekliliklerini erteleyerek emek piyasasında uzunca bir süre yer almalarının sebebi çoğu zaman ekonomik sorunlar olarak nitelendirilmektedir. Bu durumda başlangıç seviyesinde çalışan genç yeteneklerin kurum içerisinde ilerlemesi zorlaşacağından gençler farklı kurumlardaki şartları değerlendirerek sahip oldukları yetenekleri ile yükselme potansiyellerinin olduğu yerlere geçiş yaparak kariyerlerinde ilerlemeye çalışmaktadırlar. Böyle bir süreçte tüm seviyelerdeki işlerde emek piyasasından ayrılışın yada emekliliğin ertelenmesi yeni işe alımları azaltacağından yeni bir depresyon durumu ortaya çıkmaktadır (Wellins ve diğ., ty. S. 2-4). Bu durumun önüne geçebilmenin en önemli unsuru 60 yaş ve üzeri çalışanlardan farklı çalışma (örneğin kısmı süreli çalışma) modelleri ile faydalanarak onları koç, mentor şeklinde çalıştırmaktır. Böylelikle 60 yaş ve üzeri bu grup hem emek piyasas1 içerisinde yer alarak yeni yeteneklerin geliştirilmesine katkıda bulunacak, hem de işgücü piyasasındaki işsizlik seviyesi daha da aşağıya çekilerek emek piyasalarındaki çarkın hızlı bir biçimde dönmesi sağlanacaktır (Yumurtacı, 2013, s. 27-29). 
198 • YALOVA SOSYAL BİLİMLER DERGİSİ

\section{Yetenek Yönetiminde İşlerin ve Çalışanların Sınıflandırılması}

Yetenek yönetiminde işlere ve çalışanlara yönelik sınıflandırma yol haritas1 sağlamak, uzun vadede işin etkinliği, karlılık ve verimlilik açısından büyük önem taşımaktadır. İşin ihtiyaç duyduğu gerekliliklere göre çalışanların belirlenmesi ancak doğru bir sınıflandırmanın ve stratejinin izlenmesi ile mümkün olmaktadır. Bu konuda Huselid ve diğerlerinin (2005, s. 3) yetenek yönetimi yaklaşımlarına bakıldığında işler; A, B ve C sınıfı pozisyonlar olmak üzere üçe ayrılarak gruplandırılmaktadır. Bu işlerden ilki olan A sınıfı işler stratejik öneme sahiptirler. B sınıfına giren işler ise, destek görevi görmektedirler. Buna karşılık C sınıfına giren işler diğer işler olarak adlandırılmakta olup, A ve B sınıfına giren işlere oranla daha az stratejik önem arz etmektedirler. Ancak burada dikkat edilmesi gereken nokta A sınıfına giren işlerin bir kuruma ait organizasyon şemasında sürekli en üstte yer alan işler olmayacağıdır. A sınıfı olarak ifade edilen işler orta ve/veya daha alt kademedeki işleri de kapsayabilmektedirler. Bu durumda bu işlerde çalışacak kişilerde de yüksek performans ve yüksek potansiyel gücü aranmaktadır (Huselid ve diğ., 2005, s. 3). Böylelikle stratejik önemi bakımından performansı ve potansiyeli yüksek olan kişilerin A sınıfına giren işlerde çalışması, performansı yüksek olup potansiyeli düşük olan kişilerin ise, B sınıfındaki işlerde çalışması beklenmektedir. C sınıfındaki işlerde çalışanlar ise stratejik etki bakımından hem A hem B sınıfındaki işlere göre ikame edilmesi daha kolay olan grubu içermektedir (Polat, 2011, s. 6). Bahsedilen bu durumlar çalışanları yerine koyma zorluğu ve işin katma değeri bakımından yapılan sınıflandırma ile Tablo 1 ile gösterilirken, Tablo 2 ile çalışan performansı ve potansiyeli bakımından çalışanların sinıflandırılmasına yer verilmektedir.

Tablo 1: Yetenek Yönetiminde İşlerin Sınıflandırılması

\begin{tabular}{|c|c|c|c|}
\hline & \multicolumn{2}{|c|}{ İŞIN KATMA DEĞERİ } \\
\hline & & DÜŞÜK & YÜKSEK \\
\hline \multirow{2}{*}{$\begin{array}{c}\text { YERINE } \\
\text { KOYMA } \\
\text { ZORLUĞU }\end{array}$} & ֻู & $\begin{array}{l}\text { Yerine Koymak zor } \\
\text { Düşük Katma Değer }\end{array}$ & $\begin{array}{l}\text { Yerine Koymak zor } \\
\text { Yüksek Katma değer }\end{array}$ \\
\hline & $\stackrel{\pi}{\varrho}$ & $\begin{array}{l}\text { Yerine Koymak kolay } \\
\text { Düşüik Katma değer }\end{array}$ & $\begin{array}{l}\text { Yerine Koymak kolay } \\
\text { Yüksek Katma değer }\end{array}$ \\
\hline
\end{tabular}

Kaynak: Lewis ve Heckman, 2006. 
Tablo 2: Yetenek Yönetiminde Çalışanların Sınıflandırılması

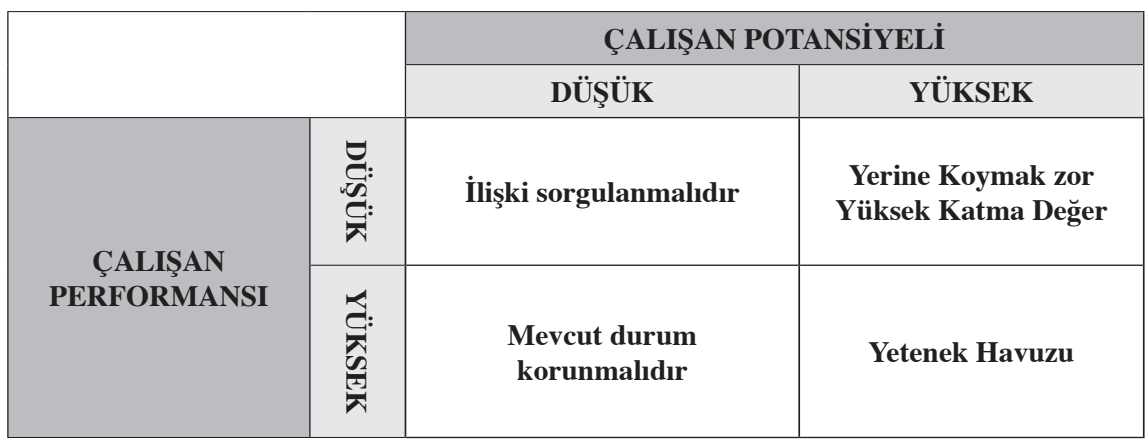

Kaynak: Polat, 2011.

Kurum içi pozisyonların tanımlanmasında insan kaynaklarına göre kurumda en önemli pozisyonlar yüksek beceriye sahip, sorumluluk duygusu yüksek, çalışkan ve kendini değişen koşullara ve çevreye adapte edebilen kişilerle doldurulmalıdır. Kurum için önem taşıan pozisyonlar olarak ifade edilen pozisyonlar kurumun stratejik hedefleri açısından değerlendirilerek belirlenmelidir. Öyle ki aynı işi yapan, aynı sektördeki iki şirket için anahtar pozisyonlar farklılık gösterebilmektedir. Örneğin, perakende sektöründe müşteri memnuniyetinin esas alındığ kurumlardan birinde temel hedef bireysel hizmetlere ağırlık verilmesi olurken, bir diğer kurumda fiyatlardaki düşüklük müşteri memnuniyetini sağlayabilmektedir. Bu durumda kurum içi pozisyonların s1nıflandırılması konusunda iki kurumun uygulayacağ 1 strateji de birbirinden farklı olacaktır. Dolayısı ile farklı birimlerde yer alan işgücünün bir kısmı A sınıfındaki pozisyonlarda hizmet verirken geri kalan işgücü $\mathrm{B}$ ve $\mathrm{C}$ sınıfindaki pozisyonlarda yer alabilmektedir. Bu pozisyonlar farklı ölçütler bakımından Tablo 3'te gösterilmektedir.

Tablo 3: Yetenek Yönetiminde Farklı Kriterlere Göre

A, B ve C Sinıfi Pozisyonlar

\begin{tabular}{|c|c|c|c|}
\hline & $\begin{array}{l}\text { A Sinıfı } \\
\text { Pozisyonlar }\end{array}$ & $\begin{array}{l}\text { B Sinıfi } \\
\text { Pozisyonlar }\end{array}$ & $\begin{array}{l}\text { C Sinıfı } \\
\text { Pozisyonlar }\end{array}$ \\
\hline $\begin{array}{l}\text { Ölçütlerin } \\
\text { Tanımlanması }\end{array}$ & $\begin{array}{l}\text { Direkt Stratejik Etki } \\
\text { Bu pozisyonlarda } \\
\text { yüksek } \\
\text { performans ve } \\
\text { potansiyel sergilenir }\end{array}$ & $\begin{array}{l}\text { Dolaylı Stratejik } \\
\text { Etki } \\
\text { Potansiyel Stratejik } \\
\text { etki ama bu tip } \\
\text { pozisyonlarda düşük } \\
\text { Performans } \\
\text { sergilenir }\end{array}$ & $\begin{array}{l}\text { Az derecede } \\
\text { stratejik etki }\end{array}$ \\
\hline
\end{tabular}




\begin{tabular}{|l|l|l|l|}
\hline Yetki Düzeyi & $\begin{array}{l}\text { Bağımsız karar } \\
\text { verme }\end{array}$ & $\begin{array}{l}\text { Belirli süreçler takip } \\
\text { edilerek karar verme }\end{array}$ & $\begin{array}{l}\text { İşte inisiyatif } \\
\text { düşüktür }\end{array}$ \\
\hline Ücret Belirlenmesi & Performans & İş seviyesi & Piyasa fiyatları \\
\hline $\begin{array}{l}\text { Değer Yaratmanın } \\
\text { Etkisi }\end{array}$ & $\begin{array}{l}\text { Önemli derecede } \\
\text { gelir yaratır veya } \\
\text { maliyeti azaltır }\end{array}$ & $\begin{array}{l}\text { Değer yaratan } \\
\text { birimleri destekler }\end{array}$ & $\begin{array}{l}\text { Ekonomik etkisi } \\
\text { düşüktür }\end{array}$ \\
\hline Hatanın Sonuçları & $\begin{array}{l}\text { Yüksek maliyete yol } \\
\text { açabilir ve önemli } \\
\text { derecede gelir kaybı } \\
\text { vardır }\end{array}$ & $\begin{array}{l}\text { Yüksek maliyete yol } \\
\text { açabilir ve değeri } \\
\text { azaltır }\end{array}$ & $\begin{array}{l}\text { Maliyetli olması } \\
\text { gerekli değildir }\end{array}$ \\
\hline $\begin{array}{l}\text { Yantış } \\
\text { Sonuçları }\end{array}$ & $\begin{array}{l}\text { Önemli eğitim } \\
\text { maliyeti ve gelirde } \\
\text { kayıp }\end{array}$ & $\begin{array}{l}\text { köreceli olarak } \\
\text { kolaylıkla pozisyon } \\
\text { doldurularak çare } \\
\text { bulunur }\end{array}$ & $\begin{array}{l}\text { Yeni kişilerin } \\
\text { bulunması B sınıfı } \\
\text { işlerden daha } \\
\text { kolaydır }\end{array}$ \\
\hline
\end{tabular}

Kaynak: Huselid, Beatty ve Becker, 2005'ten yararlanılarak hazırlanmıştır.

\section{Yetenek Yönetiminde Yeteneği Belirleyen Faktörler}

Genel anlamda yeteneğin nitelik ve niceliğini dört faktör belirlemektedir. Bu faktörler sırasıyla; küresel ekonomik ve demografik süreçler, işgücü hareketliliğinin artması, iş çevrelerinde, becerilerde ve kültürel yapılardaki değişimsel hareketler ve emek piyasasındaki çeşitliliktir. Bu faktörler başlık olarak verilmek yerine içeriklerinin daha iyi anlaşılabilmesi açısından her biri kısaca özetlenmektedir.

\subsection{Küresel Ekonomik ve Demografik Süreçler}

Azalan doğum oranları, artan yaşam süreleri ile beraber yaş grafiğinin artış göstermesi nüfusun genel yapısında olduğu gibi işgücü arzında da yaşlanma meydana getirmektedir. Bu durum yetenek yönetimi sürecinin de ye- 
niden şekillenmesine sebep olmaktadır (Yumurtacı, 2007, s. 10). Özellikle yaşlanmanın yoğun olarak yaşandığı gelişmiş ülkelerde ileri teknolojilerden faydalanılarak süreci kendileri açısından olumlu yöne taşıma çalışmaları hız kazanmaktadır. Öyle ki küresel işgücü hareketleri özellikle nüfusları yaşlanan gelişmiş ülkelerin yakından ilgilendiği alanlar haline dönüşmektedir. $\mathrm{Bu}$ durum beraberinde yetenek için savaşları ve daha fazla mücadele etmeyi meydana getirmektedir.

\section{2. İşgücü Hareketliliğinin Artması}

Küreselleşme ile sınırların kalkması beraberinde işgücünün hareketliliğini de arttırmaktadır. Günümüzde genellikle beyin göçü olarak ifade edilen bu durum ile yetenekli işgücü diğer çalışan gruplarına nazaran daha hareketli hale gelmektedir. Ancak kimi durumlarda da tersine göç ile birlikte ülkelerine geri dönenler yüksek seviyedeki eğitim ve sektör deneyimleri neticesinde gittikleri ülke ile kendi ülkeleri arasında köprü görevi oluşturmaktadır. Bu durumda yeterli ve etkili hükümet politikaları ile tersine göç dinamik bir şekle dönüştürülmeli ve beyin döngüsünün işlerliği arttırılmalıdır. Bu şekilde ülkeler arasında ikili işbirliği sağlanarak bilgi alışverişinin yaygınlaştığı yeni bir sistemin oluşturulması hedeflenmelidir.

\section{3. İs Çevrelerinde, Becerilerde ve Kültürrel Yapıdaki Değişimler}

Sadece sermayeye dayalı üretimi içeren bir ekonomik yapıdan bilgi temelli bir sisteme geçildiğinde, yetenek için savaşların küresel anlamdaki etkileri farklı sonuçları ortaya çıkarmaktadır.

Gelişmiş ülkelere bakıldığında bu ülkelerde hizmet sektörünün ağırlık gösterdiği görülmektedir. Örneğin; AB'de işlerin \%71'ini hizmet sektörü oluşturmaktadır. Hizmet sektörü üzerine şekillenen ekonomiler insan sermayesi üzerinde olan yatırımlarını daha da arttırmaktadırlar. Hizmet sektöründe kurumlar artık yetenekli çalışanları işe almak, onları elde tutmak, bu çalışanların verimliliklerini artırmak için eskisinden daha fazla etkinlik göstermektedirler. Organizasyonel gelişim ve kültür açısından bakıldığında kurumların artık gelişim dinamikleri içerisinde hızlı gelişim ve değişim göstermeyen çalışanları kurum dışına ittikleri görülmekle birlikte, gelişim gösteren yetenekleri bulmak için çaba harcadıkları dikkat çekmektedir. Bu durumda başta ülkeler olmak üzere kurumların bürokratik ve hiyerarşik yapılarını alt seviyelere indirerek yetenekli işgücünün bulunması konusunda hız kazanmaları ve yeni teknolojileri kullanarak sisteme uyum sağlamaları gerekmektedir. 


\subsection{Emek Piyasalarındaki Çeşitlilik}

Küresel bir ortamda faaliyet gösteren kurumların yapısına bakıldığında birbirinden farklı çalışanlar ve çalışma şekillerinin mevcut olduğu bir emek piyasası dikkat çekmektedir. Artık bir kurumun içerisinde etnik açıdan, kültürel açıdan, kuşak (nesil) ve cinsiyet açısından farklı işgücü yer almakla birlikte işgücünün sayısının ve çeşitliliğinin her geçen gün arttığı görülmektedir. Öyle ki bir kurum hatta daha belirgin olarak bir ofis içerisinde iki hatta üç kuşağın bir arada çalıştığına şahit olunmaktadır. Bebek patlaması kuşağından, $\mathrm{X}$ ve $\mathrm{Y}$ kuşağına kadar çalışanların bir arada olması bunun bir göstergesidir.

Bununla birlikle kadın istihdamının emek piyasasındaki artışı ile yetenekli kadın çalışanların kuruma çekilmesi, pozisyonların kadın işgücü ile doldurulması ve böylelikle kadınların işgücü içerisinde daha etkin bir biçimde elde tutulmasını sağlayıcı politikalar oluştuğu görülmektedir. Özellikle eskiden stratejik önem arz eden pozisyonlar için yalnızca birkaç kadın çalışan istihdam edilirken yetenek yönetimi uygulamaları ile daha fazla oranda kadın çalışanın bu pozisyonlarda çalıştığ 1 bu anlayışı doğrulamaktadır (Beechler \& Woodward, 2009, s. 274-275).

\section{Yetenek Yönetiminin Sorumluları}

Yetenek Yönetimi konusunda kurum içerisinde kimler sorumludur? sorusuna verilen cevap genellikle insan kaynakları birimi şeklinde olsa da genel olarak yetenek yönetimi uygulamalarından kurumda bulunan herkesin sorumlu olduğunu söylemek mümkündür (Trudel, 2011, s. 1).

Öte yandan tüm sorumluların yetenek yönetimi uygulamalarında tek başına çalışması da bir anlam ifade etmeyeceği için sorumluların işbirliği içerisinde çalışmaları, enerji ve çabalarını gerek kurum içinden çalışanları kurumda tutmak, gerekse de kurum dışından yetenekli çalışanları kuruma çekmek için harcamaları gerekmektedir. Ancak böyle bir uygulama ile yetenek yönetiminden başarılı sonuçlar elde edilmesi beklenmektedir (Abudi, 2011, s. 1 ).

\subsection{Yetenek Yönetiminde Üst Düzey Yöneticilerin Rolü}

Bugün pek çok kurum yeteneğin kendileri için en önemli varlık olduğunu savunmaktadır. Ancak bu duruma çalışanlar açısından bakıldığında bazı çalışanlar yetenek yönetimi uygulamalarının sadece teoride kaldığını düşünmektedir. Bu bakış açısının değişmesi için uygulamaya ağırlık verilerek yeteneğin ve yeteneği yönetmenin ne derecede önemli olduğu çalışanlara hissettirilmelidir. Bahsedilen bu durum bizlere Kelleher'in bir sözünü hatırlatmaktadır; "Çalışanlarınıza müşterilerinizmiş gibi davranın, bu şekilde onlara doğru bir tutum- 
la yaklaştığınızda çalışanlarınız da müşterilerinize doğru bir biçimde davranırlar". Kelleher'in bu ifadesi yetenek yönetimi anlamında düşünüldügünde üst düzey yönetimin yetenek yönetimi sürecinde sahip olduğu etkinin organizasyonel gelişim açısından ne derecede önemli olduğu görülmektedir.

Özellikle günümüz koşullarında rekabetin yoğunlaşması ile yetenekli çal1şanlara ulaşmak ve onları kurumumuza çekmek açısından durum daha da büyük önem arz etmektedir. Öyle ki kurumun gelecekte varlığını sürdürebilmesi için gerekli olan karlılık ve verimlilik anlayışı yetenek yönetimi uygulamaları ile değişerek, birlikte büyüyelim ve gelişelim anlayışına dönüşmektedir. Aslında kurumlar çalışanlarını geliştirmek açısından eğitim, beceri geliştirme vb. firsatlar sunarken aynı zamanda kendileri de gelişmekte ve rakiplerinin önüne geçmektedirler (Bock, 2012, s. 1).

Kurumların içerisindeki iş akışı bakımından insan kaynakları birimleri, yetenek yönetimi sürecinden sorumlu olarak görülürken üst düzey yöneticiler de yeteneklerin bulunması, yeteneklere rehberlik edilmesi, geliştirilmesi süreçlerinde azami derecede sorumluluğa sahip olmaktadırlar (Ulrich \& Smallwood, 2009, s. 116-118). Bu noktada yetenek yönetimi açısından üst düzey yöneticilerin tanımlayıcı, değerlendirici, geliştirici ve yetenekleri örtüştürücü bakımdan etkinlik sağladığı görülmektedir (Trudel, 2011, s. 1). Konu ile ilgili "The Economist Intelligence"nin çalışmasında yetenek yönetiminde sorumluluk dağılımı bakımından üst düzey yöneticilerin etkinliği ortaya konmaktadır. Çalışmanın sonucuna göre; yaklaşık 20 üst düzey yönetici ile yapılan görüşmede yöneticilerin çoğunun işte geçen çalışma sürelerinin \%20-50'lik kısmını yetenek yönetimine ayırdığı ortaya çıkmaktadır. Üst düzey yöneticilerin yetenek yönetimine bu derecede önem vermelerinin sebebi organizasyonel gelişimde en fazla rol oynayan unsurun emek olmasıdır (The Economist Intelligence, 2006, s. 3). Bu durumu destekleyici olarak bugün pek çok üst düzey yöneticinin yetenek yönetimine harcadıkları sürenin artması ile birlikte bulundukları kurumun verimlilik oranındaki artışların önceki birkaç yıla göre yaklaşık olarak iki ila üç katlık artış gösterdiği görülmektedir. Bunun için yetenek yönetimi şu anda ve gelecekte mutlaka üst düzey yöneticilerin ajandalarında bulunması gereken konuların başında yer almalıdır.

\subsection{Yetenek Yönetiminde Orta Düzey Yöneticilerin Rolü}

Orta düzey yöneticilerin onayladığ çalışma planları ve iş stratejileri kuruma ait yetenek yönetimi sisteminin uygulanmasında kullanılmaktadır. Bunun sebebi yetenek yönetiminin iş stratejisinin odak noktası olmasıdır (Trudel, 2011, s. 1). Durum iş stratejileri, çalışma planları ve yetenekleri kapsayan üçlü bir yapı içerisinde değerlendirildiğinde, kurum içerisindeki yetenekleri geliş- 
tirecek ve onları daha ileri noktalara taşıyacak olan sadece üst yönetim veya insan kaynakları birimleri değildir. Aslında yetenek yönetimi sürecinde etkinliği en fazla olan kişiler orta düzey yöneticilerdir. Ancak orta düzey yöneticiler yeteneklerin yönetiminde düşünüldüğü kadar istekli değillerdir. Bunun çeşitli nedenleri olmakla birlikte, en bilinen nedenleri yetenek geliştirme sürecinin ayrı bir emek ve zaman gerektirmesi, günlük iş akışının yanında yeteneklerin yönetilmesi ile ilgili süreçlerin orta düzey yönetici için fazladan bir yük oluşturması anlayışıdır. Başka bir nedeni ise, orta düzey yöneticilerin kendilerinden daha yetenekli bir çalışanı yetiştirmeleri ile birlikte ileride bu yeteneğin kendisini yetiştiren orta düzey yöneticisinin yerine geçerek yöneticisinin yerini alması yönündeki endişedir. Bu noktada en büyük görev üst düzey yönetime düşmekte olup, açık bir iletişim ile birlikte bu endişenin ortadan kaldırılması gerekmektedir. $\mathrm{Bu}$ durumda orta düzey yönetime düşen en büyük görev ise, organizasyonel gelişimi ve başarıyı engelleyecek davranışlardan uzaklaşmak ve yetenekli çalışanları en etkili şekilde yöneterek kurumun geleceği açısından gerekli emek, zaman ve özveriyi göstermeleridir (Çırpan \& Şen 2009, s. 116). $\mathrm{Bu}$ şekilde bugünün ve geleceğin yeteneklerinin bulunması, geliştirilmesi, kurum içinde tutulması ve organizasyonun başarılı bir büyüme göstererek rekabet koşullarında ayakta kalması sağlanacaktır (Grossman, 2007, s. 2).

\subsection{Yetenek Yönetiminde İnsan Kaynakları Bölümünün Rolü}

Bir kurum ile ileride o kurumda çalışma olasıllı̆̆ bulunan kişilerin ilk karşılaşacağı birimin insan kaynakları birimi olması yetenekli çalışanların kuruma çekilmesi bakımından insan kaynakları yöneticilerine yetenek yönetimi süreci boyunca stratejik bir görev yüklemektedir. Artık insan kaynakları birimlerinin görevleri yalnızca işe girişten işten çıkışa kadarki süreçte tek başına raporlama yapmak yada bordro hazırlamak değildir. Aksine insan kaynakları son y1llarda klasik görevlerinin yanı sıra farklı bir perspektifte hareket etmektedir. Bu durumda insan kaynakları yöneticilerinin küresel koşullardaki değişimler karşısında kendilerini yenilemeleri, uzmanlaşmaları, şartlara ve organizasyonun stratejilerine, adayların yapısına daha geniş ve farklı bir bakış açısı ile bakmaları, farklılığı ve çeşitliliği avantaj olarak görmeleri gerekmektedir. Aksi takdirde rekabet koşullarının her geçen gün hız kazandığg günümüz dünyasında ihtiyaç duyulan yeteneklerin kuruma çekilmesi zorlaşacaktır (Jayne, 2006, s. 19).

Günümüzde yetenek yönetiminin dünyada artan önemi karşısında çoğunlukla yetenek yönetimi sürecinin uygulayıcıları olan insan kaynakları birimlerinin etkinliği de artmaktadır. Bu durum insan kaynakları uygulamalarını stratejik açıdan destekleyen insan kaynakları profesyonelleri açısından olum- 
lu bir durumdur. Yapılan araştırmalar göstermektedir ki yetenek yönetimi sürecine rehberlik eden ve yetenek yönetimi sürecinde ortaya yeni fikirler sunan insan kaynakları yöneticileri klasik hale gelmiş uygulamaların yanı sıra yeni iş hedeflerinin belirlenmesi ve yeni gelişimsel programların hayata geçirilmesinden de sorumlu olmaktadirlar (The Economist Intelligence, 2006, s. 8). Bu bağlamda yetenek yönetimi sürecinin hayata geçirilmesinde insan kaynakları birimlerinin temel görevleri sürecin içerisinde yer alan diğer sorumlularla etkileşim halinde olarak destek, disiplin ve sürekli geliştirme faaliyetlerinde yer almalarıdır. Bu uygulamaya ek olarak insan kaynakları birimleri insan kaynaklarının tüm fonksiyonlarının (işe alım, performans değerleme ve ücretlendirme, eğitim vb.) içerisine yetenek yönetimi uygulamalarını aktif bir biçimde yerleştirerek organizasyonel gelişime katkıda bulunmalıdırlar (Çırpan \& Şen, 2009, s. 116).

\subsection{Yetenek Yönetiminde Çalışanların Rolü}

Yetenek yönetimi sistemi açısından çalışanların sahip oldukları yetenekler organizasyonel gelişim sağlanmasında doğrudan etkili olmaktadır. Çalışanlar kurumun amaçları doğrultusunda kendi performans hedeflerini geliştirmekten sorumludurlar. Çalışanların performans geliştirme planlarının uygulanması sonucu ortaya çıkan performansları ile ilgili olarak yöneticilerinden aldıkları geri beslemeler onların gelişimini sağlamakta etkin olmaktadır. Bilinçli bir şekilde hareket eden çalışanların yöneticileri ile sağlayacağı işbirliği ile organizasyonel başarıda gözle görülür bir gelişme beklenmektedir. Böylelikle yöneticileri tarafindan en doğru biçimde kariyer planı yapılan yeteneklerin motivasyonu artacağı gibi, çalıştıkların işe ve kuruma olan bağlılıklarında pozitif yönde bir ilerleme kaydedeceği düşünülmektedir.

Özetle yetenek yönetiminde sorumluluklar açısından her kurumun kendine özgü bir sistem uygulayarak etkili bir yetenek yönetimi ekibine sahip olması gerekmektedir. Bu ekip üst düzey yöneticiler, birim yöneticileri ve uzmanlar, insan kaynakları birimi ve çalışanlardan oluşan bir yapıyı içermelidir. Bu taktiksel takım insan kaynakları planlaması doğrultusunda ortaya çıkacak işgücünü gözden geçirme, değerlendirme, yeni iş gücü sağlama, geliştirme açısından yetenek yönetimi sistemi ve stratejisi oluşturarak uygulanabilir bir yetenek yönetimi anlayışını hayata geçirmeyi hedeflemelidir (Trudel, 2011, s. 1).

\section{Yetenek Yöneticisinin Sahip Olması Gereken Özellikler}

Başarılı bir yetenek yönetimi süreci için öncelikle bu sürecin uygulayıc1ları olan yetenek yöneticilerinin sahip olması gereken temel özellikler bulunmaktadır. Bu özellikler empati, esinleme, başkalarını geliştirme olarak sınıf- 
landırılırken ayrıca sosyal beceri düzeyinin en üst seviyede kullanılmasını da gerektirmektedir. Bunlar sırası ile şöyle açıklanmaktadır;

$>$ Empati: Empati yönü güçlü yöneticiler duygusal anlamda duruma net bir biçimde hakim olabildiklerinden söz ile açıklanamayan ancak duygusal yönden hissedilen olguları sezebilmektedirler. Empati anlayışı üst düzeyde olan yöneticiler yetenekleri dinledikten sonra yeteneklerin etkin bir biçimde değerlendirilmelerine dair düşüncelerini zihinlerinde net bir tabloya dönüştürebilmektedir.

$>$ Esinleme: Esinleme becerisini üst düzeyde kullanabilen bir yönetici ortaya koyabileceği ortak vizyon- misyon ve değerler yaklaşımı ile yetenekli çalışanları aktif duruma geçirmektedir. Böylece ortak bir amaç etrafında hareket etmenin getireceği hazzı kuruma olduğu kadar çalışanlara da yansıtmaktadır. Bu durumda esinleme özelliğine sahip yöneticiler ilgi uyandırdıkları gibi ilham da vermektedirler.

Başkalarını Geliştirmek: Etkin bir yetenek yöneticisi sahip olduğu yada ileride muhtemelen sahip olacağı yetenekli çalışanları geliştirmek yönünde aktif rol üstlenmektedir. Özellikle karşısında yer alan yetenekli çalışanın hedeflerini bilmekte ve buna göre bu çalışana ait güçlü ve zayıf yönleri aynen kurumlara ait somut analizler gibi masaya yatırmaktadır. Böylelikle ortaya çıkan sonuçta yetenek yöneticisinin doğru zamanda ve koşullarda yapacağ 1 geri besleme ile gerçekçi bir amaç belirlenirken etkin bir geliştirme sistemi hedeflenmektedir (Beceren, 2012, s. 1).

Temelde bu üç özelliği içselleştiren yetenek yöneticilerinin yetenek yönetiminin uygulanması sürecinde daha verimli olacakları düşünülmektedir.

\section{Küreselleşme ve Yetenek Yönetimi}

Küresel anlamda yaşanan değişikliklerle birlikte kurumsal anlamda başarıyı sağlanmanın ve bu başarıyı sürdürülebilir hale getirmenin temel unsuru yeteneklerin doğru bir biçimde belirlenmesi ve yönetilmesinden geçmektedir (Bersin, 2011, s. 8-9). Özellikle küresel pazarda stratejik role sahip yetenekli çalışanlar düşünüldüğünde, başarının anahtarının kurumun yapısal özellikleri ile çalışanların özelliklerinin örtüşmesi sonucu elde edileceği anlaşılmaktadır. $\mathrm{Bu}$ açıklamalardan hareketle küresel anlamda yetenek yönetiminden beklentiler şu şekilde ifade edilmektedir;

$>$ Küresel yetenek yönetimi yetenek stratejileri içerisinde iş stratejilerinin dönüşümünü sağlayarak tüm stratejik süreçlerde yeniden yapılanmayı sağlayıcı bir köprü vazifesi görmelidir. 
$>$ Küresel yetenek yönetiminde kurum içi doldurulacak pozisyonlar belirlenerek bu pozisyonlar küresel anlamda yetenek arayışı anlayışı ile uygun yeteneklerle doldurulmalıdır. Ayrıca bu yeteneklerin seçiminde kurum kültürüne kolayca adapte olabilen ve kurum kültürünü aktif bir biçimde temsil edebilecek işgücüne ulaşabilmek hareket noktası olmalıdır.

$>$ Çalışanların kurum içine çekilmesi, yerleştirilmesi, kariyer gelişimi, eğitimi ve kurum içinde tutulması küresel süreçler göz önüne alınarak planlanmalıdır, öyle ki uluslararası standartlarda yetenek yönetim sistemleri incelenerek kurum bazında bölgesel olarak uygulanabilir sistemler oluşturmak hedeflenmelidir (Stan, 2012, s. 6).

Bununla birlikte küresel yetenek yönetimi sürecini şekillendiren farklı durumlar da bulunmaktadır. Bu durumlar; ihtiyaçtan daha az sayıda yeteneğe sahip olmak, ihtiyaçtan daha fazla sayıda yeteneğe sahip olmak, yeteneğin kurum içinde yanlış pozisyonlarda yer alması ve yeteneğe ödenen ücretlerdeki bozukluklar olarak belirtilmektedir. Buna göre ihtiyaçtan daha az sayıda yeteneğe sahip olunduğunda; yetenek havuzlarının yeniden gözden geçirilmesi gerekmektedir. Ancak kurumun belirli bir yetenek havuzu olmaması halinde işin gerektirdiği özellikler küresel boyutta düşünülerek yetenek arayışına geçilmesi yönünde hareket edilmelidir. İkinci durum olan ihtiyaçtan fazla yetenek ile karşılaşılması durumunda; yetenekler kurumun bünyesel özelliklerine göre farklı ülkelerde açılacak stratejik iş birimlerinde görevlendirilmelidirler. Üçüncü olarak yetenekler kurum içerisinde yanlış pozisyonlara yerleştirilmişler ise, bu kişileri işten çıkarmak hem kurum adına, hem de çalışanlar adına doğru bir yaklaşım olarak nitelendirilmemektedir. Bu durumdaki çalışanları sahip oldukları yetenekler göz önüne alınarak maksimum fayda sağlayabilecekleri iş birimlerine yönlendirmek hedeflenmelidir. Böyle bir durumda işten çıkarma uygulanacaksa ortaya çıkacak maliyet ve kurumun prestij kaybı hesaba katılmalıdır.

Son olarak yetenekli çalışanlara ödenen ücretin yapısındaki bozukluklar değerlendirildiğinde, kurumun kendi bünyesinde oluşturduğu ücretlerin küresel piyasalardaki ücret politikaları ve ülkesel ücret politikaları göz önüne alınarak yeniden değerlendirilmesi ve optimum fayda sağlayacak (hem çalışanlar, hem de kurum açsından) yaklaşıma göre karar verilmelidir (Schuler ve diğ., 2011, s. 506-516 ).

Bununla birlikte 21. yy'da dünyada artan işgücü hareketliliği ile yüksek yeteneklere sahip bireyler için küresel piyasalarda iş firsatlarının hız kazandığ görülmektedir. Öyle ki artık yetenekler henüz aktif anlamda işgücü piyasasına adım atmadan fark edilmekte ve kuruma kazandırılmaya çalışılmaktadırlar. $\mathrm{Bu}$ durumun en somut örneği yüksek öğrenim sürecinde olan öğrencilerdir. 
Bireyler genellikle üniversite sonrasında herhangi bir alanda yüksek lisans veya doktora derecesi almak için yurt dışına gittiklerinde eğitimleri sonrasında aldıkları iş teklifi ile gittikleri ülkede birkaç yıl kalıp kendi ülkelerine geri dönüyorlarsa bu beyin döngüsüdür. Ancak eğitimleri sonrasında aldıkları iş tekliflerini uzun vade için değerlendirip gittikleri ülkede kalıyorlarsa bu beyin göçüdür (Solimano, 2003, s. 15-20).

Yetenek için savaşlarda önem arz eden durum beyin göçü ve beyin döngüsünün ülkelere sağlayacağı fayda ya da zarardır. Küresel anlamda hız kazanan yetenek yönetimi uygulamaları ile yurt dışına giden öğrencilerin eğitimleri sonrası bir kısmının ülkelerine geri döndüğü, geri dönmeyenlerin ise, eğitimlerini tamamladıkları ülkenin emek piyasasında başta özel sektör ve üniversite araştırma merkezleri olmak üzere, endüstri, devlet, çok uluslu şirketlerde ça1ışmaya başladıkları görülmektedir. Özellikle uluslararası yatırım projelerinin gerçekleştirilmesinde yetenekli çalışanlara duyulan ihtiyaç önemli boyuttadır. Teknik, idari ve danışmanlık alanında projelerde çalışan bu kişilerden temel beklenti çalışmaya başladıkları ülkedeki işlere kolay uyum sağlayabilmeleridir. Çalışanların temel beklentileri ise, sahip oldukları yetenekler ile kariyer gelişimlerini devam ettirebilecekleri ortamın olup olmaması, iki ülke (kendi ülkeleri ile bulundukları ülke) arasındaki ücret farkları ve yaş faktörüdür. $\mathrm{Bu}$ durumda yetenekli işgücü açısından ücretin tek başına çekici unsur olmadığı görülmektedir. (Mc Namee Center for Digital Strategies at The Tuck School of Business, 2008, s.4-11 ). Bu sebeple beyin göçü yerine beyin döngüsü ile yetenekli işgücünün küresel anlamda becerilerini geliştirebileceği bir ortamın mümkün kılınması temel amaç olmalıdır. Böylelikle sahip olunan yetenekli işgücü ile kalkınmanın hız kazanması sağlanacağı gibi işini severek yapan, motivasyonu yüksek mutlu çalışanlara sahip olunacağı düşünülmektedir.

\section{Sonuç ve Öneriler}

21.yy'ın bilgi toplumlarında organizasyonlar için stratejik değer arz eden temel konu emeğin doğru bir biçimde kuruma çekilmesi, geliştirilmesi ve kuruma bağlılığının sağlanmasıdır. Bu noktada rekabet koşullarının hız kazanması ile kurum için gerekli olan yeteneğe zamanında ulaşmak önem arz etmektedir. Böyle bir durumda yetenek yöneticilerinin stratejik bir bakış açısı ile hareket etmeleri ve küresel süreçleri göz önünde bulundurmaları gerekmektedir. Başarılı bir yetenek yönetimi süreci için, üst düzey yöneticiler süreci sadece insan kaynakları birimlerinin görevi olarak görmemelidirler. Bu konuda Odom'un “70-20-10 Modeli”ni uygulayarak zamanlarının \%70'ini çalışanlarını geliştirme faaliyetlerine, \%20'lik kısmını görev ve davranış odaklı koçluk ve mentorluk uygulamalarına ayırmalıdırlar. Geriye kalan \%10'luk dilimi ise, günlük 
işleri için kullanmalıdırlar. İnsan kaynakları birimleri ise, üst düzey yönetimce belirlenen yeteneklerin bulunması ve geliştirilmesi aşamasında strateji gelişimine katkıda bulunmalıdırlar (Borne, 2012, s. 1). Gerekli stratejilerin belirlenmesinin ardından kurum içerisinde yetenek standardını belirlemeli ve bu standarda göre yetenek havuzları oluşturulmalıdır. Ancak planlı bir biçimde gerçekleştirilebilecek liderlik anlayışı ile yetenek yönetiminin istenen standarda sahip olması beklenmektedir. Bu noktada yetenek yönetimi sürecinin etkin olup olmadığını tespit etmek için kurumlar adına yetenek yöneticileri kendilerine şu soruları sormalıdırlar;

> İşi anlamlandırma ve çalışan memnuniyeti bakımından çalışanlarımızla beraber çalışıyor muyuz?

$>$ Çalışan eğitimine inanıyor muyuz ve bu yönde neler yapıyoruz?

> Çalışanlarımızı becerilerini geliştirmeleri yönünde destekliyor muyuz?

$>$ Çalışanlarımızın iş dışındaki yaşantılarına saygı gösteriyor muyuz? (Lee, ty.).

$>$ Çalışanlarımızın işlerini severek ve isteyerek yapmalarını sağlayabilecek bir iş çevresine sahip miyiz?

> Çalışanlarımıza düşüncelerini rahatça ifade edebilecekleri ortamlar sağlıyor muyuz yoksa kendi fikirlerimizde 1 srarcı mı davranıyoruz?

$>$ Çalışanlarımız kurumumuzda çalışırken sahip oldukları yetenekleri kullanabildiklerini düşünüyorlar mı?

> Sahip olduğumuz yetenek havuzlarını sadece bilgisayar ortamında mı bulunduruyoruz yoksa bu yetenek havuzlarının kurumumuz ve çalışanlarımız açısından uygulanabilir bir etkisi var mı?

> Sahip olduğumuz yeteneklerle biz çalışanlarımızın yerinde olsa idik kendi kurumumuzda çalışmayı tercih eder miydik?

Benzer şekilde üretilebilecek pek çok soruya çalışanlarımızın ve bizim içtenlikle vereceğimiz yanıtların yetenek yönetim sistemimizi değerlendirmek açısından önemli bir etkiye sahip olacağını söylemek mümkündür. $\mathrm{Bu}$ noktada henüz yetenek yönetimi sürecine geçmemiş olan kurumların da bu sorulara verecekleri yanıtların sahip oldukları iş stratejileri ve emek açısından kendilerini sorgulamalarında yol gösterici olacağı düşünülmektedir. Ayrıca işgücünün etkinliği açısından yakın dönemde yetenek yönetim sistemlerinin şekillenmesinde olumlu etkiler yaratacağ 1 tahmin edilmektedir. 


\section{KAYNAKÇA}

Abudi, G. (2011). Who is Responsible for Developing Talent? http://www.ginaabudi.com/ who-isresponsible-for-developing talent/management.html, Erişim tarihi: 19.11.2012.

Aykaç, M., Parlak Z. ve Özdemir, S. (2009). Küreselleşme Sürecinde Rekabet Gücünün Arttırılması ve Türkiye'de KOBI'ler, İstanbul: İstanbul Ticaret Odası Yayınları.

Beceren, E. (2012). Yetenek Yönetimi ve Sosyal Zeka.

http://www.ikpaylasim.com/yetenekyonetimi-ve-sosyal-zeka/, Erişim tarihi: 04.09.2012.

Beechler, S. \& Woodward I.C. (2009). "The Global "War for Talent”, Journal of International Management, 15, 273-285.

Bersin, J. (2011). Strategic HR and Talent Management: Predictions for 2012, Driving Organizational Performence Amidst an Imbalanced Global Workforce, Bersin \& Associates Research Report, November 2011.

Blass, E. (2007). Talent Management Maximising Talent for Business Performance,Executive Summary, Charted Management Institute and Ashridge Consulting.

Bock, H. (2012). The CEO's Role in Talent Management.

www.talentmgt.com/articles/view/the-ceo-s-role-in-talent-management, 04.12.2012.

Borne, K. (2012). Who is Responsible for Talent Management? . kurtborne.com/2012/07/25/ who-is-responsible-for-talent-management/, Erişim tarihi: 05.07.2013.

Budak, İ. (2008). Üstün Yeteneklilik Kavramı ve Tarihsel Gelişim Süreci, [Elektronik versiyon]. Journal of Qafqaz University, 1, 164-173.

Buzzle, (ty.). Talent Management. www.buzzle.com/editorials/12-16-2004-63026.asp, Erişim tarihi: 01.07.2013.

Ceylan, N. (2007). Insan Kaynakları Yönetiminde Yetenek Yönetimi ve Bir Uygulama.Yayımlanmamış Yüksek Lisans Tezi, İstanbul Üniversitesi, İstanbul, Türkiye.

Collings, D.G. \& Mellahi K. (2009). Strategic Talent Management: A review and research agenda, [Elektronik versiyon]. Human Resource Management Review, 19, 304-313.

Çırpan, H. \& Şen A. (2009). İşletmelerde Yeniliği Geliştirmede Etkili Bir Araç: Yetenek Yönetimi, [Elektronik versiyon]. Çerçeve Dergisi, Eylül Sayısı, 110-116.

Davis, E. (2011). The Critical Human Capital Issues of 2011 Report, Institute for Corporate Productivity.

Doğan, S. \& Demiral Ö. (2008). İnsan Kaynakları Yönetiminde Çalışanların Kendilerine Doğru Yolculuk Yöntemi: Yetenek Yönetimi, [Elektronik versiyon]. Çukurova Üniversitesi Sosyal Bilimler Enstitüsü Dergisi, 17, 145-166.

Eren, E. (2004). Örgütsel Davranış ve Yönetim Psikolojisi, İstanbul: Beta Basım.

Eroğlu, U. (2001). İnsan Kaynakları Yönetiminde Yeni Yönelimleri Hazırlayan İki Güç: SanalOrganizasyonlar ve Stratejik Tabanlı Düşünce, [Elektronikversiyon]. İş, Güç Endüstri İlişkileri ve İnsan Kaynakları Dergisi, 2, 1.

Giddens, A. (2000). Sosyoloji, Ankara: Ayraç Yayınevi.

Grossman, R.J. (2007). New Competencies for HR, [Elektronik versiyon]. HR Magazine, $6,58-62$. 
Huselid, M.A., Beatty R. W. ve Becker B. E. (2005). “A Players or A Positions” The Strategic Logic of Workforce Management, [Elektronik versiyon]. Harward Business Review, December, 110-117.

Jayne, V. (2006). How to Run The Talent Show, Management. August, People Issues, 19. http://www.archivesearch.co.nz/?webid=mgt\&articleid=22751, Erişim tarihi: 08.07.2013.

Lee, D. (ty.). How to Attract and Retain Great Employees. www.humannatureatwork.com, Erişim tarihi: 25.06.2013.

Lewis, R.E. \& Heckman, R.J. (2006). “Talent Management: A Critical Review”, Human Resources Management Review, 16, 139-154.

Liderinsan, (2009). Yetenek nedir? Yeteneklerimizi yönetebilir miyiz?,liderinsan.com.tr/ yetenek-nedir-yeteneklerimizi-yonetebilir-miyiz.html, Erişim tarihi: 25.06.2013.

Mc Kinsey \& Company (2001). The War for Talent Organization and Leadership Practice, McKinsey \& Company.

Mc Namee Center for Digital Strategies at The Tuck School of Business (2008). Global Talent And The Next Generation Workforce A Through Leadership Roundtable on Digital Strategies, Glassmeyer.

Okakın, N. (2005). Marmara Üniversitesi Çalışma Ekonomisi ve Endüstri İlişkileri ABD İnsan Kaynakları Yönetimi Tezli Yüksek Lisans Ders Notları, İstanbul.

Polat, S. (2011). Yetenek Yönetimi, [Elektronik versiyon]. Dosya Ankara Sanayi Odası Yayın Organı, Mayıs- Haziran 2011, 27-38.

Schuler, R.S., Jackson, S.E. ve Tarique, I. (2011). Global Talent Management and Global Talent Challenges: Strategic Oppurtunities for IHRM, [Elektronik versiyon]. Journal of World Business, 4, 506-516.

Seyyar, A. (2002). Sosyal Siyaset Terimleri Ansiklopedik Sözlük, İstanbul: Beta Basım.

Solimano, A. (2003). Globalizing Talent and Human Capital: Implications for Developing Countries.

Stan, L. (2012). Talent Management and The Cultural Influences on Human Resources Management Process A Comparison on HRM Practices Between Companies From Sweden and Romania. Master Thesis in Management, University of Gothenburg, Sweden.

The Economist Intelligence (2006). The CEO's Role in Talent Management How Top Executives from Ten Countries are Nurturing The Leaders of Tomorrow, The Economist Intelligence Unit.

Tonta, Y. \& Küçük, M.E. (2005). "Sanayi Toplumundan Bilgi Toplumuna Geçişte Temel Dinamikler, Bilgi Çağı ve Teknolojik Gelişmeler Işı̆̆ında Toplum, Yönetim, Yönetici ve Lider Yaklaşımları", Uluslararası Sempozyumu 12-13 Mayıs 2005. İstanbul.

Trudel, N. (2011). Who is Responsible for talent Management? http://www.employeeperformance.com/blog/?p=1569, Erişim tarihi: 19.11.2012.

TDK Sözlüğü, (1988). Türk Dil Kurumu Türkçe Sözlük, Ankara: Türk Tarih Kurumu Basimevi.

Wellins, R.S., Smith, A.B. ve Erker, S. (ty.). White Paper-Nine Best Practices for Effective Talent Management, Development Dimensions International.

Ulrich, D., Younger, J., Brockbank, W. ve Ulrich, M. (2012). HR From The Outside in Six Competencies for The Future of Human Resources. USA: McGraw Hill Companies. 
212 • YALOVA SOSYAL BİLIMLER DERGİSI

Ulrich, D. \& Smallwood N. (2009). Liderlik Markası, (Fadime Kahya, Çev.), İstanbul: İş Bankası Kültür Yayınları.

Yumurtac1, A. (2007). Nüfusun Yaşlanması ve Avrupa Emek Piyasalarına Etkileri. Yayımlanmamış Yüksek Lisans Tezi, Marmara Üniversitesi, İstanbul, Türkiye.

Yumurtac1, A. (2013). Demografik Değişim: Psiko-Sosyal ve Sosyo-Ekonomik Boyutları ile Yaşl11ık, [Elektronik versiyon].Yalova Üniversitesi Sosyal Bilimler Dergisi. 6, 9-33. 